\title{
Epithelioid hemangioendothelioma of the thyroid: a case report
}

\author{
Mayu Ono ${ }^{1,4^{*}}$, Yoshio Kasuga ${ }^{1}$, Takeshi Uehara ${ }^{2}$ and Yoshinao Oda ${ }^{3}$
}

\begin{abstract}
Background: Epithelioid hemangioendothelioma (EHE) of the thyroid is an extremely rare disease; only three cases have been reported in the English literature to date. Here, we describe a case involving a patient with thyroid EHE successfully treated with curative surgery.

Case presentation: A 74-year-old woman presented with a right thyroid mass. The nodule was approximately $2 \mathrm{~cm}$ in size and was diagnosed as an indeterminate lesion by fine needle aspiration cytology. She was treated with thyroid lobectomy. The histopathological and immunohistochemical findings indicated an EHE of the thyroid. At the latest follow-up, 3 years postoperatively, the patient showed no signs of recurrence.

Conclusion: There is currently no standard therapy for EHE; however, our case suggests that curative resection represents an effective treatment.
\end{abstract}

Keywords: Epithelioid hemangioendothelioma, Thyroid, Surgery

\section{Background}

Epithelioid hemangioendothelioma (EHE) is a rare vascular tumor, most commonly reported to occur in the lungs, liver, and bone, along with many other sites throughout the body [1]. The etiology of EHE is unknown. Previously, EHE was recognized as an intermediate-risk disease, classified between angioma and angiosarcoma [2]; however, in the fourth revision of the World Health Organization classification, EHE was described as a malignant vascular tumor, similar to angiosarcoma [3].

EHE of the thyroid is very rare, and only three cases have been reported to date in the English literature. Here, we describe a patient with EHE of the thyroid who underwent successful resection.

\section{Case presentation}

A 74-year-old woman was referred to our hospital because of a nodule in the right lobe of the thyroid. The nodule had been found during a medical examination

\footnotetext{
* Correspondence: mayuono@shinshu-u.ac.jp

1 Department of Breast and Endocrine Surgery, Nagano Matsushiro General

Hospital, 183 Matsushiro, Nagano 381-1231, Japan

${ }^{4}$ Present address: Department of Breast and Endocrine Surgery, lida

Municipal Hospital, 438 Yawatamachi, lida 812-8582, Japan

Full list of author information is available at the end of the article
}

performed 3 years ago, but she did not undergo a detailed examination at the local hospital at that time. On physical examination, a palpable and hard nodule of approximately $2 \mathrm{~cm}$ in size was noted in the right side of her neck. Results of the blood examination were normal, except for mildly increased thyroglobulin $(142 \mathrm{ng} / \mathrm{mL})$ and antithyroglobulin antibody levels $(59.7 \mathrm{IU} / \mathrm{mL})$. Ultrasonography and computed tomography showed a right thyroid nodule with calcification. The nodule had no signs of extrathyroidal invasion and measured $21 \mathrm{~mm}$ in diameter. The lymph nodes of the neck were not swollen (Fig. 1). The nodule was diagnosed as an indeterminate lesion by fine needle aspiration cytology. The fine needle aspiration smears showed spindle-shaped cells with prominent nucleoli and nuclear inclusion. The intercellular space was metachromatic on Giemsa staining (Fig. 2). Taken together, these findings suggested a hyalinizing trabecular adenoma, granulomatous lesion, papillary carcinoma, or poorly differentiated carcinoma.

We decided to treat this nodule as thyroid cancer. Right thyroid lobectomy and central neck dissection were performed. Macroscopically, a well-circumscribed mass in the right lobe of the thyroid was observed. Histologic evaluation of the thyroid nodule showed multinodular proliferation of oval to polygonal-shaped epithelioid cells with oval nuclei and eosinophilic cytoplasm 

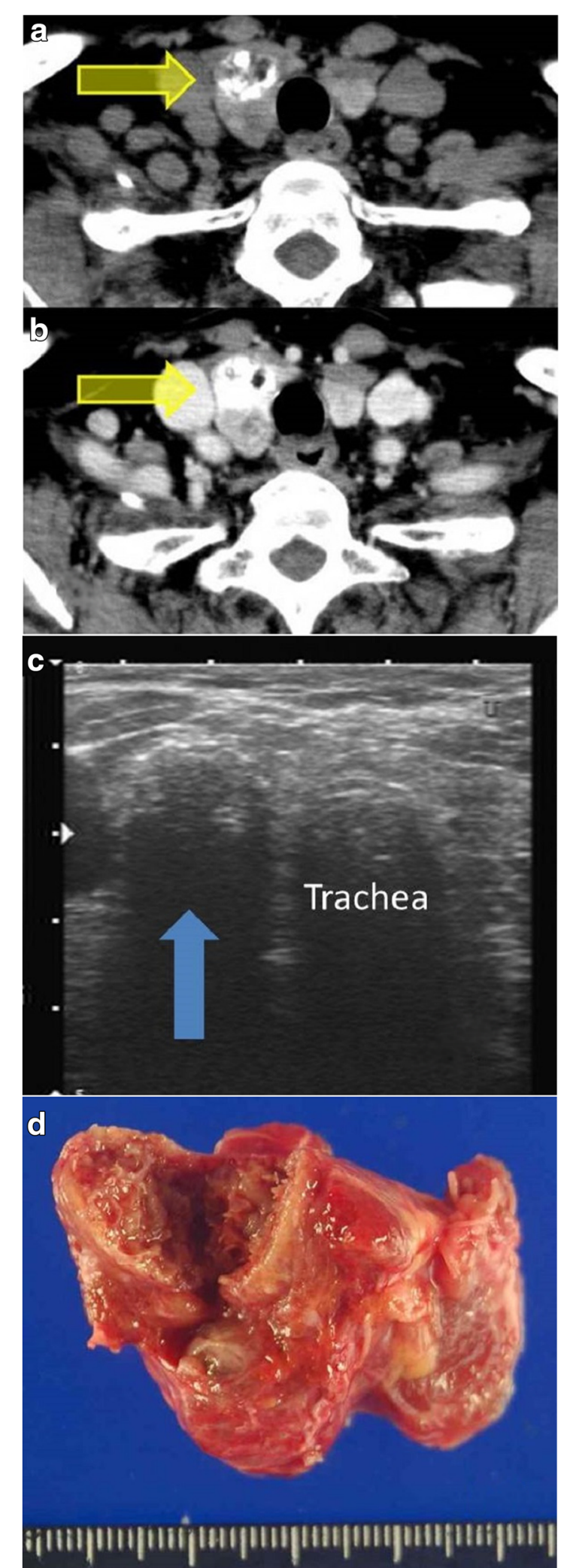

Fig. 1 Characteristics of the thyroid nodule. Computed tomography scan showing the right thyroid nodule with calcification (arrow) (a). The nodule is enhanced and shows no signs of extrathyroidal invasion (arrow) (b). Ultrasonogram showing the right thyroid nodule (21 mm in diameter) with calcification (arrow) (c). Macroscopically, a well-circumscribed mass in the right lobe of the thyroid is observed (d)

arranged in sheet- or cord-like patterns, accompanied by fibrous stroma and marked osseous metaplasia. Nuclear atypia was mild, and mitosis was not prominent. Results of the immunohistochemical staining showed that these areas were partially positive for cytokeratin, cluster of differentiation (CD)34, and factor VIII; diffusely positive for vimentin; and negative for thyroglobulin, thyroid transcription factor-1, smooth muscle actin, desmin, S100, CD31, CD68, and CD163 (Fig. 3). These findings were suggestive of EHE.

Postoperatively, the patient's thyroglobulin level fluctuated inconsistently (range, 11-292 ng/mL), as did the antithyroglobulin antibody level, although it remained positive. The mild elevation of the preoperative and postoperative thyroglobulin levels might have been caused by chronic thyroiditis. The patient has been followed-up for 3 years and has had no signs of recurrence postoperatively.

\section{Conclusions}

EHE is a rare disease, first described by Weiss et al. in 1982 [2]. The authors classified it as a vascular tumor, showing the same histological findings, but reported it as a different disease in each organ (e.g., intravascular bronchioloalveolar tumor of the lung) [4]. The 2002 World Health Organization classification changed the classification of EHE from an intermediate to malignant tumor, because some malignant clinical cases had been reported in patients with EHE. EHE most commonly presents in the liver, lung, and bone [5]. The characteristics of EHE in these common sites are shown in Table 1. In addition, Table 2 summarizes the reported EHE cases from various, rare sites of the body.

Especially, EHE of the thyroid is extremely rare [6-9], with only one case reported in the Japanese literature [9], along with three in the English literature [6-8]. These cases and our present case are summarized in Table 3.

Of note, only one of the five patients was male (20\%), which is in accordance with previous studies on EHE of other organs, in which most patients were women (male to female ratio, 1:4) [1]. There was no predominance in age (range, 35-74 years) or tumor size (range 2.1-8 cm), but all patients had a single nodule of the thyroid. On the other hand, EHE of other organs associated with multiple organ involvement in $36 \%$ of cases [5]. 


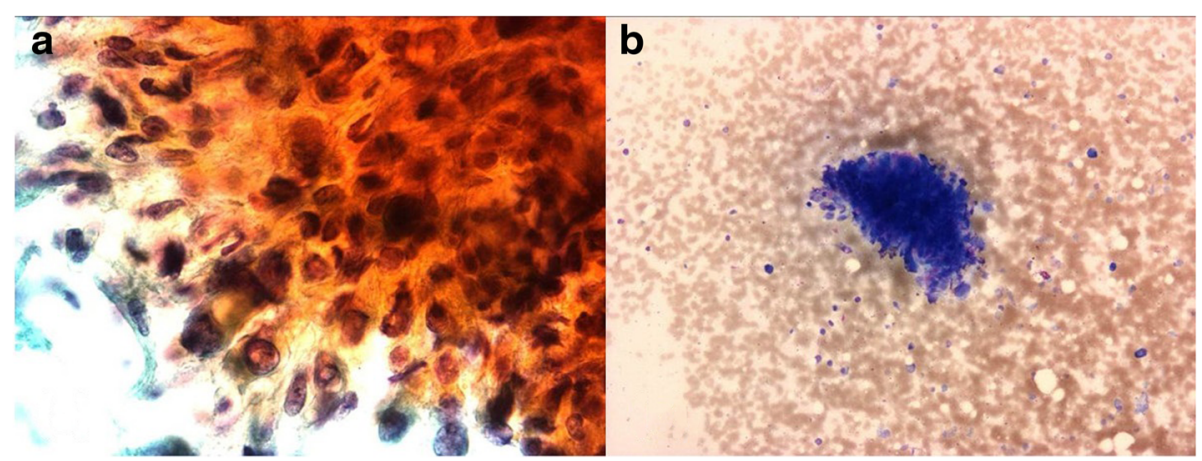

Fig. 2 Fine needle aspiration smears. Spindle-shaped cells are observed, with prominent nucleoli and nuclear inclusion (Papanicolaou stain, $\times 400$ ) (a). The intercellular space is metachromatic (Giemsa stain, $\times 100)(\mathbf{b})$

There have been several discussions on the prognostic factors of EHE, such as the presence of pulmonary lesions, multiorgan involvement, age, and sex [1]. In addition, mitotic activity ( $>3$ mitotic figures/50 highpower fields) and size $(>3.0 \mathrm{~cm})$ have been reported as risk factors for mortality in cases of EHE of the soft tissues [10]. Although the thyroid EHE patient with the largest tumor $(80 \mathrm{~mm})$ died 13 months after the diagnosis [7], the other patients, whose tumor sizes were all $<4 \mathrm{~cm}$, had uneventful outcomes $[6,8,9]$.

There is no standard treatment for EHE, although curative resection has been reported as a successful treatment with good outcomes [1]. All five patients with thyroid EHE underwent surgery. For this site, total resection can be relatively easily performed, whereas this treatment is unlikely to be performed for EHEs of other organs such as the liver, bone, and lungs. However, it is difficult to maintain a sufficient surgical margin in cases of large thyroid tumors. Our patient had the smallest tumor of the five cases, and no signs of adhesion, extrathyroidal extension, and lymph node metastasis. As mentioned above, the previously reported patient with the largest tumor experienced local recurrence and died. That tumor showed adhesion, whereas pathologically,

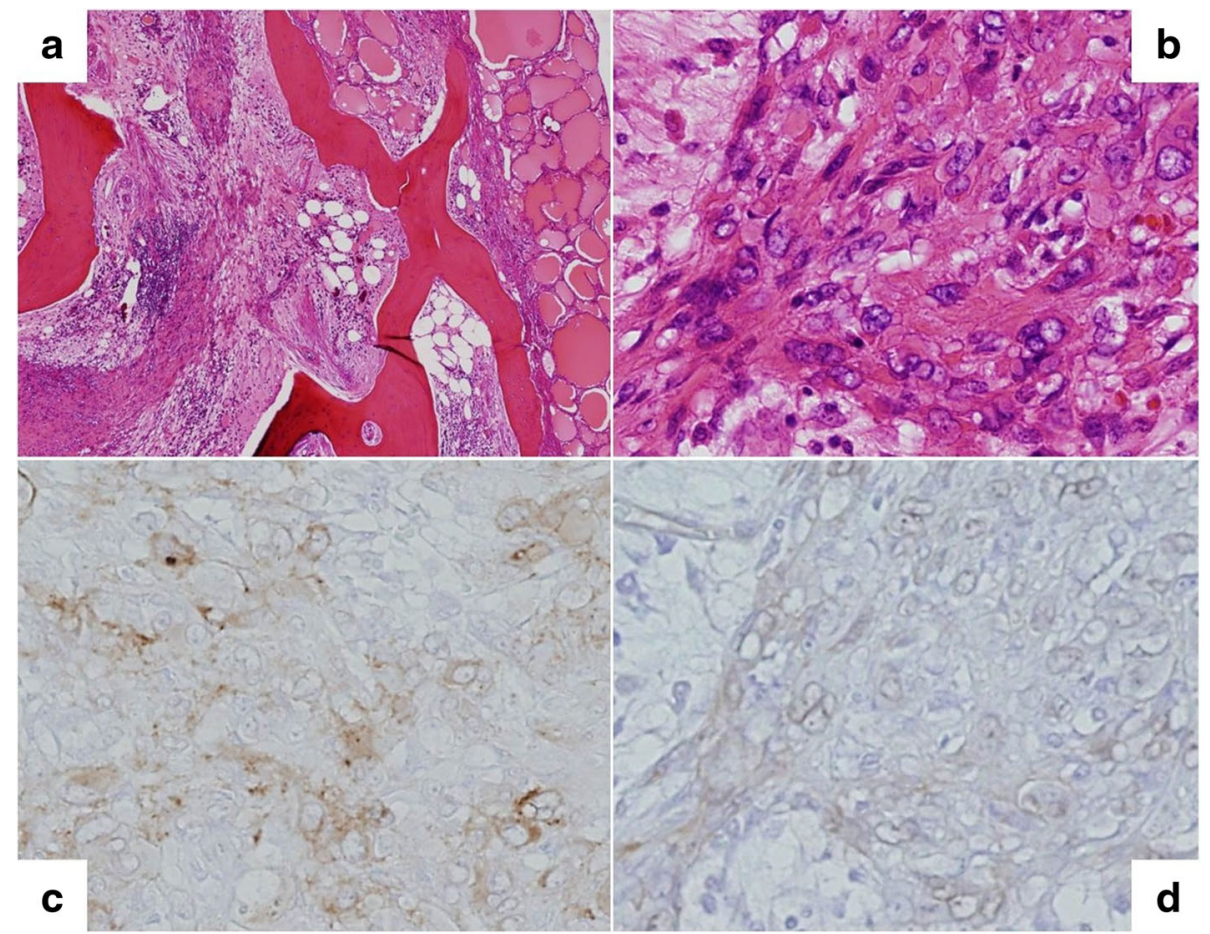

Fig. 3 Histological findings. Multinodular proliferations, composed of comparatively rich spindle cells with nuclear blebs, are observed between the trabecular bone structures. Intracytoplasmic vacuoles are also seen (a hematoxylin and eosin stain, $\times 10$; $\mathbf{b}$ hematoxylin and eosin stain, $\times 100$ ). Immunohistochemically, the tumor cells were positive for cluster of differentiation (CD)34 and factor VIII (c factor VIII, $\times 100$; d CD34, $\times 100$ ) 
Table 1 Characteristics of epithelioid hemangioendothelioma (EHE) in the liver, lungs, soft tissues, and bone (common presentations)

\begin{tabular}{|c|c|c|c|c|c|c|c|c|}
\hline \multirow[t]{2}{*}{ Site [ref] } & \multirow[t]{2}{*}{ Sex } & \multirow[t]{2}{*}{ Multicentric } & \multicolumn{2}{|c|}{ Metastasis } & \multirow[t]{2}{*}{ Management } & \multirow{2}{*}{$\begin{array}{l}\text { Survival rate } \\
\text { (5 years) }\end{array}$} & \multirow[t]{2}{*}{ Prognostic factors } & \multirow[t]{2}{*}{ Treatment } \\
\hline & & & $\begin{array}{l}\text { Rate } \\
(\%)\end{array}$ & Site & & & & \\
\hline $\begin{array}{l}\text { Liver } \\
\text { [14-19] }\end{array}$ & $M<F$ & $87 \%$ & 36.6 & $\begin{array}{l}\text { Lungs, peritoneum, } \\
\text { lymph nodes, bone }\end{array}$ & $\begin{array}{l}\text { Transplantation, } \\
\text { resection, medication, } \\
\text { radiotherapy, } \\
\text { embolization }\end{array}$ & 41 & $\begin{array}{l}\text { Extrahepatic } \\
\text { disease, vascular } \\
\text { invasion }\end{array}$ & $\begin{array}{l}\text { Chemotherapy } \\
\text { (doxorubicin, } \\
\text { cisplatin, 5FU), targeted } \\
\text { therapy (sorafenib, } \\
\text { pazopanib), IFN a-2b, } \\
\text { thalidomide, lenalidomide }\end{array}$ \\
\hline $\begin{array}{l}\text { Lung } \\
{[1,20-23]}\end{array}$ & $M<F$ & $91 \%$ & 50.5 & $\begin{array}{l}\text { Liver, pleura, lymph } \\
\text { nodes }\end{array}$ & $\begin{array}{l}\text { Lung resection, } \\
\text { medication }\end{array}$ & 60 & $\begin{array}{l}\text { Hemoptysis, } \\
\text { pleural effusion, } \\
\text { anemia, } \\
\text { thoracic symptoms }\end{array}$ & $\begin{array}{l}\text { Chemotherapy } \\
\text { (carboplatin, paclitaxel), } \\
\text { targeted therapy } \\
\text { (bevacizumab, } \\
\text { pazopanib), IFN a-2b, } \\
\text { thalidomide, } \\
\text { lenalidomide }\end{array}$ \\
\hline $\begin{array}{l}\text { Soft tissue } \\
{[10,24]}\end{array}$ & $M<F$ & $4 \%$ & 22 & $\begin{array}{l}\text { Lungs, lymph nodes, } \\
\text { liver, bone }\end{array}$ & $\begin{array}{l}\text { Surgical resection, } \\
\text { chemotherapy, } \\
\text { radiotherapy }\end{array}$ & 81 & $\begin{array}{l}\text { Mitotic activity, } \\
\text { size }\end{array}$ & ND \\
\hline $\begin{array}{l}\text { Bone } \\
\text { [25-27] }\end{array}$ & $M>F$ & $>50 \%$ & ND & Uncommon & $\begin{array}{l}\text { Wide surgical } \\
\text { resection, limited } \\
\text { surgery, radiofrequency } \\
\text { ablation, radiotherapy }\end{array}$ & $\begin{array}{l}92 \\
\text { (10 years) }\end{array}$ & $\begin{array}{l}\text { Visceral } \\
\text { involvement }\end{array}$ & \\
\hline
\end{tabular}

$M$ male, $F$ female, 5FU 5-fluorouracil, IFN interferon, ND not determined

there was no evidence of a residual tumor [7]. These findings suggest that tumor size is likely an important factor for the effectiveness of curative resection for thyroid EHE. Further studies are needed to determine the optimal surgical margin and whether lymph node dissection is sufficient for curative surgery. Moreover, two patients received radiation therapy because of lymph node metastasis. Radiation therapy may be effective to control local recurrences; however, this could not be confirmed, because the follow-up periods in the past cases were short.

Finally, the presence of CAMTA1-WWTR1 gene fusion in EHE was recently demonstrated [11]. This abnormality has been reported in the majority of EHEs at various anatomical sites, while it is absent in other epithelioid vascular tumors [11-13]. It was also confirmed in one case of thyroid EHE [8]. Therefore, fluorescence in situ hybridization analysis to detect CAMTA-

Table 2 Summary of previously reported cases of epithelioid hemangioendothelioma (EHE) occurring in rare sites

\begin{tabular}{|c|c|c|c|c|}
\hline Author [ref] & Site & Treatment & Metastasis/reccurence & Outcome (follow-up period) \\
\hline Barger [28] & Brain & $\begin{array}{l}\text { Resection(this case), chemotherapy, } \\
\text { radiotherapy, gamma knife, sunitinib }\end{array}$ & $(-) / N D$ & Alive (1 month) \\
\hline Sancheti [29] & Hypopharynx & Excision & $(-) /(-)$ & Alive (1 year) \\
\hline Boscaino [30] & Larynx & Resection & ND/ND & ND \\
\hline Pigadas [31] & Parotid salivary gland & Parotidectomy & $(-) /(-)$ & Alive (18 months) \\
\hline Moulai [32] & Heart & Chemotherapy, cardiac transplantation & $(-) /(+) 2$ years & Alive (10 years) \\
\hline Traverse [33] & Aorta & Resection & $(-) / N D$ & ND \\
\hline Charette [34] & Vein & Resection & $(-) /(-)$ & Alive (18 months) \\
\hline Versaci [35] & Stomach & Resection & $(-) /(-)$ & Alive (8 months) \\
\hline Ratan [36] & Greater omentum & Resection & $(-) /(-)$ & Alive (6 years) \\
\hline Bozkurt [37] & Adrenal gland & Laparoscopic excision & $(-) /(-)$ & Alive (6 months) \\
\hline Tolkach [38] & Kidney & Nephrectomy, sunitinib & $(-) /(+) 2 m$ & Dead (33 months) \\
\hline Liu [39] & Bladder & Transurethral resection & $(-) /(-)$ & Alive (6 months) \\
\hline Elhosseiny [40] & Penis & Local excision & $(-) /(-)$ & Alive (ND) \\
\hline Illueca [41] & Ovary & Resection & $(-) /(-)$ & Alive (1 year) \\
\hline
\end{tabular}


Table 3 Cases of thyroid epithelioid hemangioendothelioma (EHE)

\begin{tabular}{|c|c|c|c|c|c|c|c|c|c|c|}
\hline \multirow{2}{*}{$\begin{array}{l}\text { Author/year } \\
\text { [ref] }\end{array}$} & \multirow{2}{*}{$\begin{array}{l}\text { Age } \\
\text { (years) }\end{array}$} & \multirow{2}{*}{ Sex } & \multicolumn{2}{|c|}{ Thyroid tumor } & \multicolumn{2}{|c|}{ Surgical procedure } & \multirow[t]{2}{*}{ Metastasis } & \multirow[t]{2}{*}{ Adjuvant therapy } & \multirow[t]{2}{*}{ Recurrence } & \multirow{2}{*}{$\begin{array}{l}\text { Outcome } \\
\text { (follow-up period) }\end{array}$} \\
\hline & & & Location & $\begin{array}{l}\text { Size } \\
(\mathrm{mm})\end{array}$ & Thyroid & $\begin{array}{l}\text { Neck } \\
\text { dissection }\end{array}$ & & & & \\
\hline $\begin{array}{l}\text { Fujiwara/1998 } \\
\text { [9] }\end{array}$ & 56 & M & Left lobe & 30 & Lobectomy & Left lateral & $\begin{array}{l}\text { Lymph } \\
\text { node }\end{array}$ & Radiation & $(-)$ & Alive (11 months) \\
\hline $\begin{array}{l}\text { Siddiqui/1998 } \\
{[6]}\end{array}$ & 44 & $\mathrm{~F}$ & $\begin{array}{l}\text { Right } \\
\text { lobe }\end{array}$ & 37 & Lobectomy & Unknown & Unknown & $(-)$ & $(-)$ & Alive (24 months) \\
\hline $\begin{array}{l}\text { Hassan/2005 } \\
\text { [7] }\end{array}$ & 73 & $\mathrm{~F}$ & $\begin{array}{l}\text { Right } \\
\text { lobe }\end{array}$ & 80 & $\begin{array}{l}\text { Total } \\
\text { thyroidectomy }\end{array}$ & Unknown & Unknown & IFN-a & $\begin{array}{l}(+) \\
9 \text { months }\end{array}$ & $\begin{array}{l}\text { Dead } \\
\text { (13 months) }\end{array}$ \\
\hline $\begin{array}{l}\text { Shah/2016 } \\
{[8]}\end{array}$ & 35 & $\mathrm{~F}$ & Left lobe & 27 & $\begin{array}{l}\text { Total } \\
\text { thyroidectomy }\end{array}$ & Left lateral & $\begin{array}{l}\text { Lymph } \\
\text { node }\end{array}$ & $\begin{array}{l}\text { Plans for radiation } \\
\text { and chemotherapy }\end{array}$ & $(-)$ & Alive (4 months) \\
\hline Our case/2016 & 74 & $\mathrm{~F}$ & $\begin{array}{l}\text { Right } \\
\text { lobe }\end{array}$ & 21 & Lobectomy & Central & $(-)$ & $(-)$ & $(-)$ & Alive (36 months) \\
\hline
\end{tabular}

$M$ male, $F$ female

WWTR1 fusion may become a definite tool for the diagnosis of EHE in the future.

In conclusion, EHE of the thyroid is an extremely rare disease. Its clinical course varies, and the prognostic factors are unclear. Curative resection may be an effective treatment, but surgical issues such as the appropriate extent of the surgical margin and use of lymph node dissection remain to be clarified. Further studies are needed to analyze the etiology of EHE and to determine the optimal treatment.

\section{Abbreviations}

CD: Cluster of differentiation; EHE: Epithelioid hemangioendothelioma

\section{Authors' contributions}

MO drafted the manuscript. YK and MO performed the surgery and postoperative management. YK and TU revised the manuscript. TU and YO performed the pathological diagnosis. All authors read and approved the final manuscript

\section{Authors' information}

$\mathrm{MO}$ and $\mathrm{YK}$ are surgeons at the Department of Breast and Endocrine Surgery, Nagano Matsushiro General Hospital. YK is the general director of Nagano Matsushiro General Hospital. TU is an associate professor at the Department of Laboratory Medicine, Shinshu University School of Medicine. $\mathrm{YO}$ is a professor at the Department of Anatomic Pathology, Pathological Sciences, Kyushu University.

\section{Competing interests}

The authors declare that they have no competing interests.

\section{Consent for publication}

Written informed consent was obtained from the patient for publication of this case report and any accompanying images.

\section{Author details}

${ }^{1}$ Department of Breast and Endocrine Surgery, Nagano Matsushiro General Hospital, 183 Matsushiro, Nagano 381-1231, Japan. ²Department of Laboratory Medicine, Shinshu University School of Medicine, 3-1-1 Asahi, Matsumoto 390-8621, Japan. ${ }^{3}$ Department of Anatomic Pathology, Pathological Sciences, Graduate School of Medical Sciences, Kyushu University, 3-1-1 Maidashi, Higashi-ku, Fukuoka 812-8582, Japan. ${ }^{4}$ Present address: Department of Breast and Endocrine Surgery, lida Municipal Hospital, 438 Yawatamachi, lida 812-8582, Japan.
Received: 1 November 2016 Accepted: 24 January 2017

Published online: 28 January 2017

\section{References}

1. Sardaro A, Bardoscia L, Petruzzelli MF, Portaluri M. Epithelioid hemangioendothelioma: an overview and update on a rare vascular tumor. Oncol Rev. 2014;8:259.

2. Weiss SW, Enzinger FM. Epithelioid hemangioendothelioma: a vascular tumor often mistaken for a carcinoma. Cancer. 1982:50:970-81.

3. Fletcher CD, Hogendoorn P, Mertens F, Bridge J. WHO Classification of tumours of soft tissue and bone. 4th ed. Lyon: IARC Press; 2013.

4. Dail DH, Liebow AA. Intravascular bronchioloalveolar tumor. Am J Pathol. 1975;78:6a-7a.

5. Lau K, Massad M, Pollak C, Rubin C, Yeh J, Wang J, et al. Clinical patterns and outcome in epithelioid hemangioendothelioma with or without pulmonary involvement: insights from an Internet registry in the study of a rare cancer. Chest. 2011;140:1312-8.

6. Siddiqui MT, Evans HL, Ro JY, Ayala AG. Epithelioid haemangioendothelioma of the thyroid gland: a case report and review of literature. Histopathology. 1998:32:473-6.

7. Hassan I, Barth P, Celik I, Hoffmann S, Langer P, Ramaswamy A, et al. An authentic malignant epithelioid hemangioendothelioma of the thyroid: a case report and review of the literature. Thyroid. 2005;15:1377-81.

8. Shah AA, Ohori NP, Yip L, Coyne C, Antonescu CR, Seethala RR. Epithelioid hemangioendothelioma: a rare primary thyroid tumor with confirmation of WWTR1 and CAMTA1 rearrangements. Endocr Pathol. 2016;27:147-52.

9. Fujiwara K, Miura M. Epithelioid hemangioendothelioma of the thyroid gland: a case report. Pract Otorhinolaryngol. 1998;91:195-8.

10. Deyrup AT, Tighiouart M, Montag AG, Weiss SW. Epithelioid hemangioendothelioma of soft tissue: a proposal for risk stratification based on 49 cases. Am J Surg Pathol. 2008;32:924-7.

11. Errani C, Zhang L, Sung YS, Hajdu M, Singer S, Maki RG, et al. A novel WWTR1-CAMTA1 gene fusion is a consistent abnormality in epithelioid hemangioendothelioma of different anatomic sites. Genes Chromosomes Cancer. 2011;50:644-53.

12. Anderson T, Zhang L, Hameed M, Rusch V, Travis WD, Antonescu CR. Thoracic epithelioid malignant vascular tumors: A clinicopathologic study of 52 cases with emphasis on pathologic grading and molecular studies of WWTR1-CAMTA1 fusions. Am J Surg Pathol. 2015;39:132-9.

13. Flucke U, Vogels RJ, de Saint Aubain Somerhausen N, Creytens DH, Riedl RG van Gorp JM, et al. Epithelioid hemangioendothelioma: clinicopathologic, immunhistochemical, and molecular genetic analysis of 39 cases. Diagn Pathol. 2014;9:131

14. Mehrabi A, Kashfi A, Fonouni H, Schemmer $P$, Schmied BM, Hallscheidt $P$, et al. Primary malignant hepatic epithelioid hemangioendothelioma: a comprehensive review of the literature with emphasis on the surgical therapy. Cancer. 2006;107:2108-21. 
15. Cardinal J, de Vera ME, Marsh JW, Steel JL, Geller DA, Fontes P, et al. Treatment of hepatic epithelioid hemangioendothelioma: a singleinstitution experience with 25 cases. Arch Surg. 2009;144:1035-9.

16. Lerut JP, Orlando G, Adam R, Schiavo M, Klempnauer J, Mirza D, et al. The place of liver transplantation in the treatment of hepatic epitheloid hemangioendothelioma: report of the European liver transplant registry. Ann Surg. 2007;246:949-57

17. Sangro B, Iñarrairaegui M, Fernández-Ros N. Malignant epithelioid hemangioendothelioma of the liver successfully treated with Sorafenib. Rare Tumors. 2012;4, e34

18. Salech F, Valderrama S, Nervi B, Rodriguez JC, Oksenberg D, Koch A, et al. Thalidomide for the treatment of metastatic hepatic epithelioid hemangioendothelioma: a case report with a long term follow-up. Ann Hepatol. 2011;10:99-102.

19. Bally O, Tassy L, Richioud B, Decouvelaere AV, Blay JY, Derbel O. Eight years tumor control with pazopanib for a metastatic resistant epithelioid hemangioendothelioma. Clin Sarcoma Res. 2015;5:12.

20. Bagan P, Hassan M, Barthes FLP, Peyrard S, Souilamas R, Danel C, et al. Prognostic factors and surgical indications of pulmonary epithelioid hemangioendothelioma: a review of the literature. Ann Thorac Surg. 2006; 82:2010-3.

21. Amin R, Hiroshima K, Kokubo T, Nishikawa M, Narita M, Kuroki M, et al. Risk factors and independent predictors of survival in patients with pulmonary epithelioid haemangioendothelioma. Review of the literature and a case report. Respirology. 2006;11:818-25.

22. Ye B, Li W, Feng J, Shi JX, Chen Y, Han BH. Treatment of pulmonary epithelioid hemangioendothelioma with combination chemotherapy: report of three cases and review of the literature. Oncol Lett. 2013;5:1491-6.

23. Semenisty V, Naroditsky I, Keidar Z, Bar-Sela G. Pazopanib for metastatic pulmonary epithelioid hemangioendothelioma—a suitable treatment option: case report and review of anti-angiogenic treatment options. BMC Cancer. 2015;15:402.

24. Mentzel T, Beham A, Calonje E, Katenkamp D, Fletcher C. Epithelioid hemangioendothelioma of skin and soft tissues: clinicopathologic and immunohistochemical study of 30 cases. Am J Surg Pathol. 1997;21:363-74.

25. Kleer CG, Unni KK, McLeod RA. Epithelioid hemangioendothelioma of bone. Am J Surg Pathol. 1996;20:1301-11.

26. Larochelle O, Périgny M, Lagacé R, Dion N, Giquère C. Epithelioid hemangioendothelioma of bone. Radiographics. 2006;26:265-70.

27. Angelini A, Mavrogenis AF, Gambarotti M, Merlino B, Picci P, Ruggieri P. Surgical treatment and result of 62 patients with epithelioid hemangioendothelioma of bone. J Surg Oncol. 2014;109:791-7.

28. Barger J, Tanweer O, Liechty B, Snuderl M, Jafar JJ. Suprasellar epithelioid hemangioendothelioma: case report and review of the literature. Surg Neurol Int. 2016;7:S596-602.

29. Sancheti S, Singh JN, Malik A, Devi KT, Jain S. Epithelioid hemangioendothelioma of hypopharynx: a rare presentation. Indian J Dent. 2016;7:109-11.

30. Boscaino A, Errico ME, Orabona P, Tornillo L, Staibano S, Donofrio V, et al. Epithelioid hemangioendothelioma of the larynx. Tumori. 1999;85:515-8.

31. Pigadas N, Mohamid W, McDermott P. Epithelioid hemangioendothelioma of the parotid salivary gland. Oral Surg Oral Med Oral Pathol Oral Radiol Endod. 2000;89:730-8.

32. Moulai N, Chavanon O, Guillou L, Noirclerc M, Blin D, Brambilla E, et al. Atypical primary epithelioid hemangioendothelioma of the heart. J Thorac Oncol. 2006;1:188-9.

33. Traverse JH, Lesser JR, Flygenring BP, Bracken TH, Olevsky OM, Nicoloff DM, et al. Epithelioid hemangioendothelioma of the thoracic aorta resulting in aortic obstruction and congestive heart failure. Circulation. 1999;100:564-5.

34. Charette S, Nehler MR, Whitehill TA, Gibbs P, Foulk D, Krupski WC. Epithelioid hemangioendothelioma of the common femoral vein: case report and review of the literature. J Vasc Surg. 2001;33:1100-3.

35. Versaci A, Macrì A, Scuderi G, Leonello G, Fedele F, Certo A, et al. Epithelioid hemangioendothelioma of the stomach: clinical-pathological features, nosologic setting, and surgical therapy. Report of a case Surg Today. 2002; 32:274-7.

36. Ratan S, Bhatnagar V, Gupta SD, Mitra DK. Epithelioid hemangioendothelioma of the greater omentum: report of a case. Surg Today. 1999;29:919-21.
37. Bozkurt O, Demir Ö, Yener S, Tuna B, Seçil M, Yörükoğluc K. Malignant epithelioid hemangioendothelioma of the adrenal gland treated by laparoscopic excision. Urology. 2015;85:e15-6.

38. Tolkach Y, Petrov S, Lerut E, Van Poppel H. Epithelioid hemangioendothelioma of the kidney treated with sunitinib. Onkologie. 2012;35:376-8.

39. Liu B, Zhang C, Zhang Q, Liu G, Ma Z, Qi J, et al. Primary epithelioid hemangioendothelioma of the bladder: case report and review of the literature. Urol Int. 2015;94:240-3.

40. Elhosseiny AA, Ramaswamy G, Healy RO. Epithelioid hemangioendothelioma of penis. Urology. 1986;28:243-5.

41. Illueca C, Machado I, Garcia A, Covisa A, Morales J, Cruz J, et al. Uncommon vascular tumor of the ovary. Primary ovarian epithelioid hemangioendothelioma or vascular sarcomatous transformation in ovarian germ cell tumor? Arch Gynecol Obstet. 2011;284:1589-91.

\section{Submit your manuscript to a SpringerOpen ${ }^{\circ}$ journal and benefit from:}

- Convenient online submission

- Rigorous peer review

- Immediate publication on acceptance

- Open access: articles freely available online

- High visibility within the field

- Retaining the copyright to your article

Submit your next manuscript at $>$ springeropen.com 